\title{
Biological activity and phytochemical analysis of homeopathic preparations of Viscum album L.
}

\author{
Carla Holandino $^{1}{ }^{*}$, João V. da C. Batista ${ }^{1}$, Michelle N. de O. Melo ${ }^{1}$, Fortune Homsani ${ }^{1}$, Adriana \\ P. Oliveira ${ }^{1}$, Leandro M. Rocha ${ }^{2}$, Venício F. da Veiga ${ }^{3}$, Daniela S. Alviano ${ }^{3}$, Celuta S. Alviano ${ }^{3}$, \\ Mirio Grazi ${ }^{4}$, Hartmut Ramm ${ }^{4}$, Matthias Kunz ${ }^{4}$, Konrad Urech ${ }^{4}$, Ulrike Weissenstein ${ }^{4}$, Stephan \\ Baumgartner ${ }^{4}$
}

\begin{abstract}
${ }^{1}$ Multidiciplinary Laboratory of Pharmaceutical Sciences, School of Pharmacy, Federal University of Rio de Janeiro, Brazil; ${ }^{2}$ Fluminense Federal University, Niterói, Rio de Janeiro, Brazil; ${ }^{3}$ Institute of Microbiology, Federal University of Rio de Janeiro, Brazil; ${ }^{4}$ Society for cancer Research, Hiscia Institute, Arlesheim, Switzerland

*Corresponding author email: cholandino@gmail.com
\end{abstract}

\begin{abstract}
Several in vitro and in vivo studies investigated the biological properties of mistletoe preparations [1-4]. In Europe, where phytochemical eonstituents of aqueous Viscum album extracts were previously described, the most widespread and common form of mistletoe is the white-berried species (Viscum album) [5]. The aim of the present study was to analyze the biological activity and phytochemical features of different Viscum album ssp mother tinctures collected in 2 different harvesting periods.

Leaves, stems and berries of Viscum athum samples were stubjected to ethanolic extraction (45\% $\mathrm{v} / \mathrm{v}$ ) following the homeopathic pharmacopeia [6,7]. The mother tinctures (MT) prepared were: $V$. album (from 3 host trees Malus domestica, Quercus sp, Ulmus sp), V. album ssp. austriacum (host tree Pinus sylvestris) and V. album ssp. abiedis (hdst tree fbies pectinata). All samples were collected at Höfli farm (Switzerland) in July and Alugls an subectect to chemical analysis by means of highperformance liquid chromatography-mass spectrometry (HPLC-MS/MS) and Thin-Layer Chromatography (TLC). Tumor (Yoshida and Molt4) and non-tumor cells (Ma104) were incubated with MT $(1 ; 0.1 ; 0.01 \%)$ for 4,24 and 48 hours at 37 ㅇ. Proliferation was indirectly measured using WST-1 (tumor cells) and MTT (non-tumor cells). All cells $\left(1.5 \times 10^{4} / 100 \mu \mathrm{L}\right)$ were plated in triplicate in 96-well plates. The cell proliferation inhibition rate was calculated as percent inhibition relative to control cells treated with the MT solvent ( $45 \%$ ethanol v/v). Apoptosis/necrosis was measured using $2 \times 10^{5}$ cells incubated with Annexin V-FITC and 7$\mathrm{AAD}$ at room temperature in the dark, and analyzed in flow cytometer [2]. Antimicrobial activity was assessed for Candida albicans, Cryptococcus neoformans, Escherichia coli and Staphylococcus aureus following the Clinical Laboratory Standards Institute manuals [8-9] and compared with $45 \%$ ethanol v/v (MT solvent).
\end{abstract}

The chromatographic assays of MT samples showed phenolic acids and lignans as main chemical classes identified. WST-1 and MTT experiments revealed different antitumor potential of MT. In general, Yoshida cells were more sensitive than Molt4. The maximal cytotoxic effect with $100 \%$ of mortality was attained by incubation of Yoshida and Molt-4 cells with 1\% MT of V. album ssp.

Cite as: Holandino C, Batista JVC, Melo MNO, Hosmani F, Oliveira AP, Rocha LM, Veiga VF, Alviano DS, Alviano CS, Grazi M, Ramm H, Kunz M, Urech K, Weissenstein U, Baumgartner S. Biological activity and phytochemical analysis of homeopathic preparations of Viscum album L. Int J High Dilution Res. 2018; 17(1): 23-24 
Proceedings of the XXXI GIRI Meeting: 2017 Sept 7-8; Poland

International Journal of High Dilution Research 2018; 17(1):25-26

Available online at www. highdilution.org

abietis (harvested in July) for 4 hours. Preliminary results with non-tumor cells indicate lower cytotoxicity compared to tumor cells. Annexin V/7ADD showed predominance of late apoptotic/necrotic events after 4 and 24 hours of incubation with all MT. The antimicrobial assay showed that MT of Viscum album ssp. austriacum (host tree Pinus sylvestris) exhibited minimum inhibitory concentration $7.25 \mathrm{mg} / \mathrm{mL}$ for the 2 tested bacterial strains.

The results of the present study suggest that Viscum album samples prepared according to the homeopathic pharmacopeia exhibit promising biological activities in a dose-dependent manner. The effects of potentiation will be assessed and compared to non-potentiated samples in future experiments. Therefore, the present study contributes with data on the main chemical components in homeopathic preparations of Viscum album, drawing attention to the relevance of extract solvent, seasonal aspects, host tree and harvested parts of plant harvested to the quality of thee mother tinctures

Keywords: Mistletoe, Viscum album L. cancer, homeopathy, phytochemistry; cytotoxicity

\section{References}

[1] Tröger W, Galun D, Reif M, Schumann A, Stankovic N, Milicévic M. Viscum album [L.] extract therapy in patients with locally advanced or metastatic pancreatic cancer: A randomised clinical trial on overall survival. Eur J Cancer. 2013;49(18):3788-3797.

[2] Weissenstein U, Kunz M, Urech K, Regueiro U, Baumgartner S. Interaction of a standardized mistletoe (Viscum album) preparation with antitumor effects of trastuzumab in vitro. BMC Complement and Altern Med. 16:271, 2016, doi 10.1186/s12906-016-1246-2.

[3] Mulsow K, Enzlein T, Delebinski C, Jaeger S, Seifert G, Meizig MF. Impact of mistletoe triterpene acids on the uptake of mistletoe lectin by cultured tumor cells. Plos One April 18, 2016, doi 10.1371/journal.pone.0153825.

[4] Kang SN. Ethanol extracts from mistletoe (Viscum album L.) act as natural antioxidants and antimicrobial agents in uncooked pork patties during refrigerated storage. Asian Australas. J. Anim. Sci. 29: 109-118, 2016.

[5] Urech K, Baumgartner S. Chemical constituents of Viscum album L.: implications for the pharmaceutical preparation of mistletoe. Trans Res Biomed. 2015; 4:11-23, doi $10.1159 / 000375422$.

[6] ANSM. Agence Nationale de Sécurité du Medicament et des Produits de Santé. Pharmacopée Française, Preparations-homeopathiques. The General Chapters and General Monographs of the European Pharmacopoeia and Preamble of the French Pharmacopoeia apply. Mistletoe from the apple tree for homoeopathic preparations. 11e édition, Paris, 2011, pages 1-4.

[7] ANVISA. Agencia Nacional de Vigilancia Sanitária. Farmacopeia Homeopática Brasileira, 3aa ed., Ed. ANVISA, Brasilia; 2011; pages 31-33.

[8] Clinical Laboratory Standards Institute (CLSI). Methods for Dilution Antimicrobial Susceptibility Tests for Bacteria That Grow Aerobically: Approved Standard, CLSI document M07-A10. 10. Ed. Wayne, PA: Clinical and Laboratory Standards Institute, 2015/http://www.facm.ucl.ac.be/intranet/CLSI/CLSI-2015-M07-A10-original.pdf, date of access: October $1^{\text {st }}, 2017$.

Cite as: Holandino C, Batista JVC, Melo MNO, Hosmani F, Oliveira AP, Rocha LM, Veiga VF, Alviano DS, Alviano CS, Grazi M, Ramm H, Kunz M, Urech K, Weissenstein U, Baumgartner S. Biological activity and phytochemical analysis of homeopathic preparations of Viscum album L. Int J High Dilution Res. 2018; 17(1): 23-24 
Proceedings of the XXXI GIRI Meeting: 2017 Sept 7-8; Poland International Journal of High Dilution Research 2018; 17(1):25-26

Available online at www.highdilution.org

[9] Clinical and Laboratory Standards Institute (CLSI). Reference Method for Broth Dilution Antifungal Susceptibility Testing of Yeasts: Approved Standard, CLSI document M27-A3. 3. Ed. Wayne, PA: Clinical and Laboratory Standards Institute, 2008/ https://clsi.org/media/1461/m27a3 sample.pdf, date of access: October $1^{\text {st }}, 2017$.

(C) International Journal of High Dilution Research/ Not for commercial purposes.

Cite as: Holandino C, Batista JVC, Melo MNO, Hosmani F, Oliveira AP, Rocha LM, Veiga VF, Alviano DS, Alviano CS, Grazi M, Ramm H, Kunz M, Urech K, Weissenstein U, Baumgartner S. Biological activity and phytochemical analysis of homeopathic preparations of Viscum album L. Int J High Dilution Res. 2018; 17(1): 23-24 